\title{
МЈЕРЕ БЕЗБЈЕДНОСТИ И ЗДРАВЉА НА РАДУ СА ТЕРЕТНИМ ГРАЂЕВИНСКИМ ДИЗАЛИЦАМА
}

\section{HEALTH AND SAFETY MEASURES AT WORK WITH BUILDER HOIST FOR GOODS}

\author{
Маја Пејановић, Факултет техничких наука, Нови Сад
}

\section{Област - ИНЖЕЊЕРСТВО ЗАШТИТЕ НА РАДУ}

Кратак садржај - Циљ рада је да укаже на битне захтјеве безбједности и здравља на раду са теретним грађевинским дизалицама, поступак спровођења превентивних $и$ периодичних прегледа, као $u$ испитивања истих.

Кључне ријечи: теретна грађевинска дизалица, безбједност и здравље на раду, преглед, провјера $и$ испитивање.

\begin{abstract}
The goal of this master thesis is to emphasize an important requirements for safety and health at builder hoist workplace, preventive and periodic review procedures, as well as builder hoist testing.
\end{abstract}

Keywords: builder hoist for goods, health and safety at work, inspection, verification and testing.

\section{1. УВОД}

Развој грађевинарства условио је експанзију изградње високих стамбених, пословних и јавних зграда. Данас, када се захтјева знатно већи обим и интензитет радова у области грађевинарства, неопходно је користити машине изузетних техничких карактеристика и перформанси, са великом ефикасношћу обављања радних задатака.

Теретна грађевинска дизалица (позната и под именом грађевински лифт) представља уређај вертикалног транспорта терета, а по потреби и људи, при извођењу разних грађевинских радова. Ова врста дизалице се најчешће поставља са спољашње стране објекта и користи се при грађењу високих објеката на којима је потребно дизање терета и до 200 метара висине. Стуб дизалице се изводи као вертикална решеткаста конструкција са вођицама за платформу са теретом.

Дизалицом управља руковалац, тј. особа која је Циљ овог рада је да истакне најбитније захтјеве БЗНР завршила теоријску и практичну обуку за рад на истој са ТГД према расположивој литератури и укаже на и испуњава одређене здравствене услове који су недостајућу домаћу регулативу у овој области (разни утврђени љекарским прегледима. И поред прописаних правилници за дизаличне машине и сл.). Поред тога, захтјева безбједности и здравља на раду (у наставку дат је краћи осврт на поступак прегледа, провјере и БЗНР), исти често нису испуњени у потпуности у испитивања ТГД.

домаћој пракси, што за посљедицу има угрожавање безбједности и здравља радника на градилишту, животне средине и других материјалних добара.

Као што је и наведено, теретна грађевинска дизалица (у наставку ТГД, сл. 1) је најчешће смјештена са

\section{НАПОМЕНА:}

Овај рад проистекао је из мастер рада чији је ментор био доц. др Атила Зелић. спољашње стране објекта који се гради, при чему је цијелом висином конструкција стуба бочно ослоњена на објекат, у циљу обезбјеђења потребне стабилности.

ТГД се састоји од сљедећих основних цјелина:

- конструкција стуба,

- платформа за терет,

- $\quad$ погон дизања,

вођице платформе и

елементи за бочно ослањање стуба на грађевински објекат.

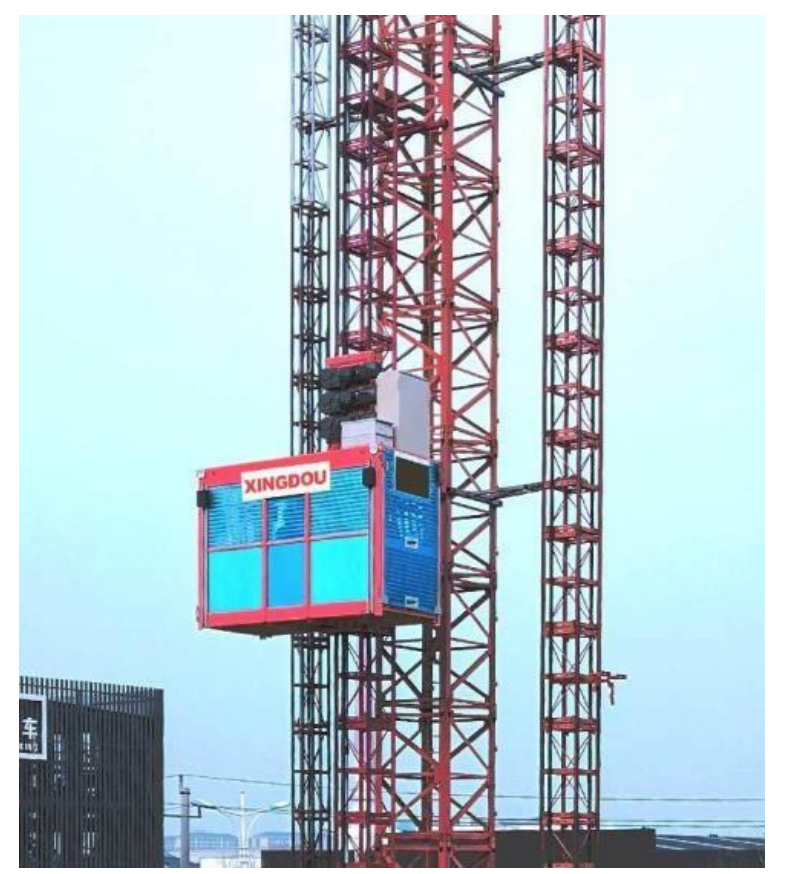

Слика 1. Теретна грађевинска дизалица.

\section{2. ПРЕГЛЕД РЕЛЕВАНТНЕ РЕГУЛАТИВЕ}

Када је ријеч о експлоатацији, као и о БЗНР са ТГД, примјенљиве су одредбе одређених важећих закона, правилника и стандарда $[1,3,4,5]$. на раду при извођењу грађевинских радова. Мјере и нормативи овог правилника примјењују се искључиво
Правилником [3] прописују се посебне мјере заштите 
унутар градилишта, а градилиште је дефинисано као простор унутар кога се изводе грађевински радови, а које би требало бити ограђено.

Законом о безбједности и здрављу на раду уређује се спровођење БЗНР лица која учествују у радним процесима и лица која се затекну у радној околини ради спречавања повреда на раду, професионалних обољења и обољења у вези са радом, што се експлицитно односи и на ТГД, [4].

Правилником [5] прописују се поступци и рокови
превентивних и периодичних прегледа, прегледи опреме за рад као и услови радне околине. Превентивним и периодичним прегледима утврђује се да ли су на опреми која се користи у процесу рада, примјењене мјере БЗНР дефинисане прописима, упутствима за рад или другом техничком регулативом.

\section{MJEPE БЗНР СА ТГД ПРЕМА SRPS EN 12158-1}

Важећи стандард [1] се бави теретним грађевинским дизалицама на моторни погон које су привремено постављене. При том, предвиђене су за коришћење лицима којима је дозвољен приступ мјестима градилишта и конструкције, и које снабдјевају претоварно мјесто и имају уређај за ношење терета. Овај стандард идентификује опасности које се јављају при раду са наведеном опремом и описује поступке смањења или уклањања опасности када се опрема користи у складу са препорукама произвођача.

\section{1 Опасности при раду са ТГД}

Опасности које су идентификоване и за које су формулисани одређени захтјеви како би се смањио ризик, односно могућност настанка нежељене посљедице опасног догађаја су сљедеће:

- $\quad$ механичке (пригњечење, увлачење или захватање, незгодан положај, удар, пробадање или убадање, огреботине, губитак стабилности, клизање, спотицање и пад), утицаји),

- опасности које производи бука (губитак слуха, ометање говора),

- опасности при операцијама дизања (недостатак стабилности, искакање платформе из шина, губитак механичке чврстоће елемената машина и прибора за дизање),

- $\quad$ опасности које су посљедица занемаривања ергономских принципа при пројектовању машина (нездрав положај тијела или повећан напор, занемарено коришћење личне заштитне опреме, стрес, људска грешка),

- $\quad$ опасности које чине материјали и супстанце које машине прерађују (контакт са прашином или маглом, пожар или експлозија),

- опасности изазване прекидом напајања енергијом, кваром машинских дијелова или

другим функционалним поремећајима (прекид напајања енергијом, грешке у прикључку, превртање, неочекиван губитак стабилности машине), опасности због недостатка и/или погрешно постављених безбједносних мјера/средстава (заштитници, уређаји за покретање и заустављање, безбједносне ознаке и сигнали, уређаји за прекид напајања енергијом).

\section{2 Конструкционе мјере БЗНР}

БЗНР се постиже првенствено конструкционим мјерама које обавезују пројектанта и произвођача дизалице, али дјелимично и корисника јер од њега зависе тежина услова рада и услови околионе.

\subsection{1 Дјеловање вјетра на платформу}

У свим случајевима прорачуна утицаја вјетра, мора се претпоставити да вјетар дува у свим правцима хоризонтално као и најнеповољнији правац дјеловања вјетра. Приликом прорачуна притиска вјетра на платформу мора се претпоставити да су сви зидови платформе, као и заштитници, чврсти.

\subsection{2 Стабилност при раду}

Основни рам мора бити пројектован тако да може да прихвати све силе које потичу од дизалице и дјелују на њега и да их пренесе на носећу површину. Уређаји који преносе силе на подлогу не смију бити пнеуматски точкови или точкови који се ослањају на опруге.

Вођице представљају дио стуба или зглобни механизам дизања. Вођице морају бити круте, а елементи као што су ужад и ланци, не смију се користити. Мора бити ограничено деформисање било ког дијела стуба или платформе тако да не може доћи до судара. Вођице и стубови морају бити тако пројектовани да издрже све случајеве оптерећења.

Кретање платформе мора бити ограничено одбојницима. У случају када не постоји горњи крајњи прекидач на платформи, морају се обезбједити одбојници на горњем крају путање.

\subsection{3 Заштитне зоне кретања ТГД и приступ} претоварном мјесту

Уграђена дизалица мора да има:

\section{-}

- $\quad$ заштиту зоне кретања дизалице,

- $\quad$ врата претоварног мјеста на свим

приступним тачкама,

чиме се обезбјеђује безбједност лица, односно наведени захтјеви онемогућују да лица буду поврјеђена покретним дијеловима или да падну. Ограда дизалице мора да заштити сваку страну до висине од најмање 2 $\mathrm{m}, \mathrm{y}$ посебним случајевима ограда дизалице може да буде мања од $2 \mathrm{~m}$.

Отварање ограде са унутрашње стране мора бити омогућено када се, због одржавања, огради приступа преко врата претоварног мјеста на основи.

Када се утовар и истовар обаваљају на нивоу тла, врата претоварног мјеста се не смију отварати према путу дизалице. Врата морају бити усклађена са захтјевима, а хоризонтална и вертикална врата морају бити вођена и њихово кретање мора бити ограничено механичким одбојницима. 
Забрањено је да се врата претоварног мјеста отварају електричне каблове који висе са платформе због њихове или затварају помоћу уређаја чији је рад механички јачине и климатских утицаја.

регулисан кретањем платформе.

Претоварна мјеста код којих се утовар и истовар обав-

3.2.7 Уређаји за ограничавање, управљање и заустављање

ља уз помоћ фиксне заштите, иста мора да постоји до Прије него што дође до контакта са крајњим најмање 1,1 m висине и мора да буде у складу са ограничавачем на крајњем претоварном мјесту, стандардом чиме је обезбјеђено да се током утовара и неопходно је да се обезбједи аутоматско заустављање истовара смањи хоризонтално растојање између ивице платформе са називне брзине на највишем и најнижем платформе и прага претоварног мјеста на највише претоварном мјесту.

$50 \mathrm{~mm}$.

Свака дизалица мора посједовати уређај за заустављање Врата претоварног мјеста морају бити тако конструи- како би се иста зауставила и држала у нерадном стању. сана да када су у затвореном положају и када се прим- Уређаји за заустављање морају да чине електрични јени сила од $300 \mathrm{~N}$ нормално на плочу у било којој сигурносни уређаји и њихова функција мора бити у тачки било које стране, при чему се сила примјењује складу са прописима. преко четвртасте или кружне површине, она морају:

- $\quad$ да издрже без трајне деформације,

- $\quad$ да издрже еластичну деформацију од $30 \mathrm{~mm}$,

- да наставе да функционишу на

задовољавајућем нивоу.

У свим случајевима сила и испуњавања критеријума, врата морају да остану сигурна што је и важно са аспекта безбједности.

\subsection{4 Платформа}

Како би се избјегло испадање или заглављивање, платформа мора бити опремљена крутим вођицама. Такође, мора посједовати ефикасан уређај који задржава платформу на вођицама у случају да откажу клизачи или точкићи.

Платформа мора бити снабдјевена и механичким уређајем који ће спријечити њено искакање из вођица. Механички уређај мора да функционише како у току нормалног рада тако и у процесу монтаже, демонтаже и одржавања.

\section{3 Експлоатационе мјере БЗНР}

Прије пуштања у рад, ТГД као и њен руковалац, морају да испуне одређене захтјеве прописане важећом регулативом:

особе које су овлашћене и задужене за то, и које су прошле одређену обуку за рад на ТГД,

- сваког радног дана мора се обавезно провјерити функционисање свих елемената ТГД,

- ТГд треба осигурати од неовлашћених поправки, преправки и пуштања у рад,

- $\quad$ настале сметње у раду са ТГД морају се одмах пријавити овлашћеној особи,

- $\quad$ након завршетка рада са ТГД, неопходно је искључити довод електричне енергије до исте,

строго је забрањено отварање врата током подизања терета, као и извођење било каквих поправки за вријеме рада ТГД.

Приликом постављања врата претоварног мјеста потребно је водити рачуна да не дође до појаве

Сви безбједносни елементи, као и платформа, морају бити обезбјеђени у свом правилном положају за кретање. Опуштање безбједносног уређаја мора бити аутоматско или мора захтјевати дјеловање руковаоца.

Под платформе мора бити тако пројектован да може да издржи све силе које се јављају, а све површине предвиђене за гажење морају спрјечавати клизање.

\subsection{5 Погонски уређај}

Свака дизалица мора да посједује бар један погонски уређај који мора бити у складу са стандардом и упутствима и укључује специјалне захтјеве.

У току нормалног рада, платформа се увијек мора подизати и спуштати помоћу погонског уређаја. Код свих врста дизалица, брзина празне платформе навише или платформе са називним оптерећењем наниже не смије да премаши називну брзину за више од $15 \%$ под нормалним радним условима.

\subsection{6 Електрични уређаји}

\section{3. ПОСТУПАК ИСПИТИВАҢА ТГД}

Сваки електрични уређај мора бити заштићен од Преглед, провјера и испитивање ТГд обавља се у штетних и опасних дејстава спољашњих утицаја складу са SRPS EN 12158-1. Укупан број испитивања не (киша, снијег, малтер, прашина). Сви каблови и смије бити мањи од 30, а иста се обављају уз укључен електрични уређаји морају бити заштићени од погон обухватајући сљедеће:

механичких оштећења. Мора се обратити пажња на 


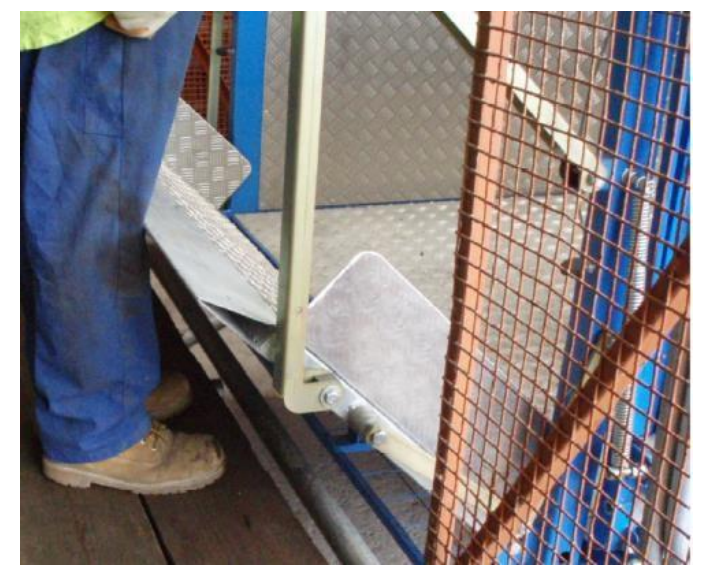

Слика 3. Опасност од пригњечења.

- 10 испитивања са називним оптерећењем,

- 5 испитивања са празном платформом,

- 5 испитивања 1,3 пута називно оптерећење,

- 5 испитивања са називним оптерећењем,

- 5 испитивања 1,3 пута називно оптерећење.
Због тога у програмима обуке треба предвидјети више практичног рада, да руковаоци вјежбају рад са уређајима и опремом за дизање, још прије него што ступе на своје радно мјесто на градилишту.

Сходно претходно наведеном, стратешки циљ надлежних институција, као и самих корисника, треба да буде усвајање одређених правилника који ће дефинисати експлоатационе мјере.

\section{5. ЗАКљУЧАК}

ТГД је врло често коришћена машина за дизање терета током извођења разних грађевинских радова. Циљ сваког радника треба да буде очување свог здравља и да води рачуна како о својој, тако и о безбједности других радника, као и да учествује у спровођењу и унапрјеђењу система БЗНР на радном мјесту. Једино на тај начин се могу успјешно спровести мјере безбједности и здравља на раду.

Битно је нагласити да је неопходно на државном нивоу унифицирати садржаје теоријских и практичних обука Прије прве употребе, произвођач мора да изврши дизаличара, односно правилницима дефинисати све
статичка и динамичка испитивања како би било релевантне мере БЗНР и детаљније смјернице за сигурно да је дизалица исправно произведена и преглед, провјеру и испитивање ТГд у складу са састављена и како би се провјерило да су сви потребни хармонизованим стандардима.

уређаји у исправном стању.

Прегледе опреме за рад обавља правно лице које посједује лиценцу за поступке прегледа и провјере опреме за рад, као и одговарајуће инструменте за обављање прегледа и провјере. За извршени преглед и провјеру опреме за рад издаје се стручни налаз. Између осталог, стручни налаз садржи закључак да ли су на прегледаној и провјереној опреми за рад примјењене или нису примјењене прописане мјере за БЗНР, односно да ли је опрема безбједна за рад [5].

\section{4. КРИТИЧКИ ОСВРТ НА РАЗМАТРАНУ ПРОБЛЕМАТИКУ}

Нажалост, у Р. Србији не постоји довољан број правилника (чак ни основни важећи правилник) за безбједан и здрав рад са дизалицама, нити генералне смјернице за обуке руковалаца. Уједно, у овој области велики проблем представља и недостатак стручне литературе на српском језику што је отежало и писање овог рада. Како би се смањио број акцидената на градилиштима, првенствено је потребно усвојити нове правилнике за одређене групе дизалица, по угледу на развијене земље као што су нпр. СР Њемачка и Руска Федерација. Усвајањем и примјеном нових правилника обука дизаличара била би много квалитетнија, а биле би јасније и детаљније дефинисане експлоатационе мјере БЗНР, као и поступци прегледа, провјере и испитивања наведене опреме за рад.

Безбједно радно мјесто постиже се само кроз заједничку сарадњу надлежних државних органа, разних института за БЗНР, произвођача и корисника опреме за рад. Евидентно је да разне обуке за дизаличаре у Р. Србији не обезбјеђују увијек довољно часова практичног рада са дизалицама, па руковаоци неопходне вјештине и сигурност стекну тек након дужег периода рада на градилиштима.

\section{6. ЛИТЕРАТУРА}

[1] SRPS EN 12158-1 - Теретне грађевинске дизалице, Дизалице са дозвољеним приступом на платформе. [2] Safeguarding Requirements for Landing Gates of Goods Only Construction Hoists, Construction Plant-hire Association, London, 2012.

[3] Правилник о заштити на раду при извођењу грађевинских радова, Сл. гласник РС, бр. 53.

[4] Закон о безбједности и здрављу на раду, Сл. гласник РС, бр. 101/05

[5] Правилник о поступку прегледа и провјере опреме за рад и испитивање услова радне околине, Сл. гласник РС, бр. 94/06

\section{Кратка биографија:}

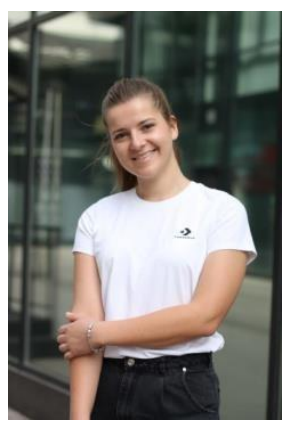

Маја Пејановић рођена је у Требињу 1997. године. У родном мјесту завршила је гимназију „Јован Дучић“. Дипломирала је 2019. године на Факултету техничких наука у Новом Саду, смјер Инжењерство заштите животне средине. Мастер рад на смјеру Инжењерства заштите на раду одбранила је 2021. године. 